\title{
Reproductive biology of the critically endangered endemic Mediterranean plant Coincya rupestris subsp. rupestris (Spain): the effects of competition and summer drought on seedling establishment
}

\author{
Biología reproductiva de la planta endémica mediterránea amenazada Coincya rupestris \\ subsp. rupestris (España): efectos de la competencia y sequía estival en el establecimiento \\ de plántulas
}

MIGUEL A. COPETE ${ }^{1 *}$, JOSÉ M. HERRANZ ${ }^{1} \&$ PABLO FERRANDIS ${ }^{1}$

${ }^{1}$ Department of Plant Production and Agricultural Technology, Escuela Técnica Superior de Ingenieros Agrónomos,
University of Castilla-La Mancha, Campus Universitario s/n,02071 Albacete, Spain
*e-mail for correspondence: Miguel.Copete@uclm.es

\begin{abstract}
Flower, fruit, seed production, and flowering phenology (duration, intensity, moment and synchrony) were studied in the two main populations (south east Spain) of the critically endangered endemic Mediterranean plant Coincya rupestris subsp. rupestris (Cruciferae). Production of flowers and fruits (mean \pm SD) ranged from 483 $( \pm 688)$ to $748( \pm 636)$, and from $317( \pm 518)$ to $553( \pm 500)$, respectively, between populations. In addition, the average seed production per plant was 1,607-2,798, thus concluding that fertility was not responsible for the rarity of this taxon. The fruit/flower ratio ranged from 0.60 to 0.75 , showing significant inter-population differences. Flowering extended from February-March to the end of spring, with high synchrony $(\approx 85 \%)$. This parameter was negatively correlated with duration of the flowering period. The role of pollinator insects on reproductive success, and the effect of watering treatments and the elimination of competitors on seedling recruitment were analysed in the classical locality. The exclusion of pollinators dramatically affected fructification, reducing reproductive success from moderate values in plants exposed to insects $(\approx 0.5)$ to null values in those where insects were experimentally excluded. Seedling emergence was autumnal and no influence of the factors analysed (i.e., water availability and inter-specific competition) was detected on seedling establishment. A high interannual variability in the size and survival of cohorts originated each autumn was observed. It should be emphasized that the rarity of the taxon is not due to fecundity restrictions.
\end{abstract}

Key words: Iberian endemism, flowering phenology, reproductive success, seedling recruitment.

\section{RESUMEN}

Para el endemismo amenazado mediterráneo Coincya rupestris subsp. rupestris (Cruciferae) se analizaron diferentes aspectos de su biología reproductiva como la producción de flores, frutos y semillas, y la fenología de la floración a través de las variables representativas de la misma (duración, intensidad, momento y sincronía), de forma independiente en las dos poblaciones principales del taxon (sureste de España). La producción de flores por planta (media \pm DE) osciló entre $483( \pm 688)$ y $748( \pm 636)$ en las dos poblaciones estudiadas, y la de frutos entre $317( \pm 518)$ y $553( \pm 500)$, con valores medios de 1.607-2.798 semillas/planta, por lo que la rareza de la especie no parece debida a su baja fertilidad. La razón frutos/flores osciló entre 0,60-0,75, con diferencias significativas entre poblaciones. La floración se extendió desde febrero-marzo hasta finales de primavera, con valores de sincronía muy elevados $(\approx 85 \%)$. Además esta variable presentó una correlación negativa con respecto a la duración. Por otra parte, únicamente en la población clásica del taxon, se analizó el papel de los insectos polinizadores en el éxito reproductivo, así como el efecto de tratamientos de riego y eliminación de la competencia en el reclutamiento de plántulas. Claramente, la exclusión de insectos polinizadores tuvo un efecto negativo en la fructificación, pasándose de un éxito reproductivo intermedio con insectos polinizadores $(\approx 0,5)$, a otro prácticamente nulo con exclusión. La emergencia de plántulas fue otoñal y no se detectó influencia de los factores evaluados. Se observó una elevada variabilidad interanual en el tamaño y supervivencia de las cohortes de plántulas originadas cada otoño. La principal conclusión derivada del trabajo es que la rareza del taxon no viene impuesta por restricciones en su fecundidad.

Palabras clave: endemismo ibérico, fenología de la floración, éxito reproductivo, reclutamiento de plántulas. 


\section{INTRODUCTION}

Effective conservation and management of rare and endangered plants require knowledge of more than just taxonomic status, distribution, and abundance of the species concerned. Reproductive biology has important consequences for the viability of rare plant populations through its effects on demography and population genetics, so its study is also crucial in conservation programs (Synge 1981, De Mauro 1993, Weller 1994, Evans et al. 2003).

Coincya rupestris Porta \& Rigo ex Rouy subsp. rupestris (tribe Brassiceae, Cruciferae) has an extremely restricted geographic distribution. In fact, the taxon is confined to two locations in the Alcaraz mountain range (Albacete, south east Spain), and a small area in Ciudad Real (central Spain), which is occupied by a transitional morphotype between rupestris and leptocarpa subspecies (GómezCampo et al. 2001). According to IUCN criteria (2001), it has been classified as "critically endangered" in the more relevant red lists of threatened flora in Spain (Bañares et al. 2003). It was also included in the National Catalogue of Threatened Species (BOE 1990) and in Appendix II of the directive "habitat" (92/43/ CEE). The regional Government of Castilla-La Mancha promulgated the recovery program for C. rupestris subsp. rupestris (DOCM 1999) which explicitly emphasizes the need for enhancing knowledge of reproductive biology in order to effectively protect the taxon. In addition, both localities in Alcaraz were protected by the establishment of microreserves (DOCM 2003, 2004).

Since the family Cruciferae is cosmopolitan, showing a broad world distribution with many species of economical interest (Izco 2004), reproductive biology has been profusely studied in this family (e.g., Conner \& Rush 1996, Evans et al. 2000, Williams \& Conner 2001). The studies on Coincya genus, however, have focused on diverse aspects such as systematic (Leadlay \& Heywood 1990), threat degree on a particular taxon (Herranz et al. 2004), risk of hybridisation (Facey et al. 2007), variability of fruit morphology (Gómez-Campo 1977, Gómez-Campo et al. 2001), and ecology of germination (Herranz et al. 2003, Copete et al. 2005), with the study of reproductive biology being of secondary importance. Gómez-Campo (1977), Vioque et al. (1994) and Gómez-Campo et al. (2001) have shown evidence of $C$.rupestris subsp. rupestris having the most evolved traits within the genus.

According to Leadlay \& Heywood (1990), cross-pollination dominates in Coincya species due to the existence of a genetic mechanism of self-incompatibility, although self-fertilization can also occur. Bees, bee flies and less frequently beetles and butterflies are the main pollinators. Gómez-Campo (1999) pointed out that such a reproductive system is predominant in the tribe Brassiceae.

In this study, several aspects of the reproductive biology of $C$. rupestris subsp. rupestris such as flower, fruit and seed production, flowering phenology, reproductive success, and factors operating on seedling recruitment have been studied. Seed production can determine the number and quality of descendents (Lorne \& Burns 2001). Torres et al. (2002) emphasized the relationship between fertility and long-term viability of a population. Information on flowering phenology is crucial to understanding the reproductive ecology of plant species (Ollerton \& Lack 1992), since flowers represent the main resource in reproductive terms, and also the mechanism of reproductive isolation and speciation (Kearns \& Inouye 1993). Therefore, this is a notable aspect to be considered in studies on reproductive biology of plant species (Kelly 1993), and abundant literature on this topic is available (e.g., Guitián \& Sánchez 1992, Kelly 1992, Torres et al. 2002). The study of reproductive success in threatened species can provide valuable information for the identification of obstacles threatening the viability of populations (Torres et al. 2002). A low seed/ovule ratio has been shown as a reliable indicator of inbreeding depression, which ultimately results in a loss of genetic variability within populations (De Mauro 1994). Seedling establishment is considered one of the most critical stages in the life cycle of plants in Mediterranean ecosystems (Rey \& Álcantara 2000, Traveset et al. 2003, Rodríguez-Pérez 2005). The seedling stage is even more important for endangered species (Walck et al. 1999) since the establishment of new individuals is essential for the persistence of populations, and inter-annual fluctuations 
usually reflect variations in seed production in different years (Mazer \& Wolfe 1998). In Mediterranean environments, irregular rainfall and summer drought often make water a limiting resource (Tyler \& D'Antonio 1995, Sánchez \& Peco 2004). Water availability is a key factor in determining the patterns of seedling establishment in these communities (García-Fayos et al. 2000, Lloret et al. 2005). In addition, although adult shrubs have been suggested to have a facilitating effect on seedling recruitment in these ecosystems (Peñuelas \& Filella 2003, Pugnaire et al. 2004, Lloret et al. 2005), competition for light and soil resources may have a negative effect (Thébaud et al. 1996, Fulco et al. 2001, Valladares \& Pearcy 2002).

The goals of the present study were: (1) to assess the production of flowers, fruits, and seeds in the two populations of $C$. rupestris subsp. rupestris; (2) to recognize patterns in the flowering phenology; (3) to determine reproductive success and the importance of pollinator insects; and (4) to evaluate the effect of several factors on seedling recruitment, survival of cohorts from different years, and inter-annual variability in the size of cohorts.

\section{MATERIAL AND METHODS}

\section{Taxon and habitat traits}

Coincya rupestris subsp. rupestris is a polycarpic perennial herb. Seedlings emerge in early autumn, usually during October and November. Flowering starts in the second spring after emergence when plants are around 18 months old. The initial number of flowering juveniles is low (15.98\%) increasing with age (26.32\% at month 30). Most matured plants die after fructification, as well as many underdeveloped juveniles which do not reach reproductive stages. However, a minor mature population fraction (16.84\%) behaves as polycarpic (unpublished data). Census during 1997-2003 showed the yearly fraction of flowering plants ranging from 10 to $25 \%$ in the total population. Heterocarpy is highly pronounced in the taxon, with two well differentiated portions in the siliqua: the dehiscent valvar portion and the beak. The latter is formed by the enlarged indehiscent stylar portion and contains a higher number of seeds than the valves.

Records and experiments for the study were carried out in La Molata (Alcaraz), the classical locality of the taxon, during 2000-2003. In addition, flower production and flowering phenology were also studied in El Estrecho del Hocino (Salobre). Both localities are in the Alcaraz mountain range, in the province of Albacete (south east Spain). The main characteristics of these localities are summarised as follows:

La Molata (MO hereafter); UTM coordinates: 30SWH47; altitude: 1,000-1,100 m; annual rainfall: $648 \mathrm{~mm}$; annual average temperature: $13.0{ }^{\circ} \mathrm{C}$; habitat of $C$. rupestris subsp. rupestris: fissures and ledges on calcareous-dolomitic rocks.

El Estrecho del Hocino (EH hereafter); UTM co-ordinates: 30SWH37; altitude: 900$940 \mathrm{~m}$; annual rainfall: $627 \mathrm{~mm}$; annual average temperature: $13.8{ }^{\circ} \mathrm{C}$; habitat of $C$. rupestris subsp. rupestris: fissures and ledges on quartzitic rocks.

During the 2001 census, 1,423 plants (280 flowered) were counted in MO, and 1,757 (347 flowered) in $\mathrm{EH}$. In the MO population, there is evidence of wide inter-annual fluctuations in the number of flowering plants, ranging from 50 to 1,360 in previous studies (Domínguez et al. 1996, Copete 2005).

\section{Flower, fruit, and seed production}

The study began during the elongation phase of flowering stems. Forty plants with growing flowering stems were selected in MO, and 25 in $\mathrm{EH}$. In order to avoid influences of exposition and substrate factors, selection was restricted to plants growing in their typical habitat: fissures and ledges on shady exposures. All of them had a vigorous and healthy appearance and were free of competitors in an area $20 \mathrm{~cm}$ around. From 15 February to 30 May 2001, flowers, fruits, and aborted flowers were counted once a week. Abortion was detected by the lack of enlargement of the ovaries in comparison with contiguous flowers in the raceme. Counts were stopped prior to seed dispersion, and the total number of flowers and ripe fruits per plant were quantified. Seed production was assessed from seed count in eight fruits per plant, collected randomly. 


\section{Flowering phenology}

Flowering phenology was studied in the same plants selected for the study of flower, fruit and seed production. Parameters analysed were moment, duration, intensity, and synchrony of flowering (Iriondo et al. 1998, Albert et al. 2001). The moment was calculated by counting days from the first bloom in the plant to the day of the maximum flower count. Duration was defined as the days elapsed from the beginning to the end of flowering in each plant. Intensity was estimated as the maximum number of flowers on a census day in a given plant. Synchrony was defined as the overlap, in days, of the flowering of an individual plant with that of the other plants. For each plant, synchrony was calculated by the following function

$$
\mathrm{S}=\frac{1}{\mathrm{n}-1} \frac{1}{\mathrm{e}_{\mathrm{i}}} \sum_{\mathrm{j}=1}^{\mathrm{n}-1} \mathrm{e}_{\mathrm{j}=\mathrm{i}}
$$

where, $\mathrm{n}=$ number of plants flowered, $\mathrm{e}_{\mathrm{i}}=$ time (in days) during which an individual (i) is flowering, $e_{j=i}=$ time (in days) during which two individuals ( $i$ and $j$ ) are simultaneously flowering.

\section{Reproductive success and pollinators}

Reproductive success or fertility is assessed as the product of the fraction of flowers producing fruits by the fraction of ovules producing seeds (Charlesworth 1989). In order to determine such ratios, 10 plants were selected at random from the sample used in the analysis of the flowering phenology in MO. In each plant, flowers and fruits were counted in four racemes. In addition, ovules produced and seeds ripened were counted in two siliquas of each raceme (i.e., eight fruits per plant).

For the analysis of the importance of pollinators, six plants in the process of flowering (i.e., with incipient flowering stems) were randomly selected in MO in mid-February 2001. Each one was enclosed by a cage of 0.1 $\mathrm{mm}$-mesh nylon. Cage dimensions were $50 \mathrm{~cm}$ x $50 \mathrm{~cm}$ and $100 \mathrm{~cm}$ high. Nylon impeded the passage of insects, but neither light intensity nor potential anemogamous pollination were affected, since pollen-grain size usually ranges from 10 to $60 \mu \mathrm{m}$ (Niklas 1994). Counts similar to those described in the previous section were taken in the plant-enclosed sample.
A possible relation between reproductive success and threat degree was investigated by extending the experiment to other taxa phylogenetically close to $C$. rupestris subsp. rupestris (Gómez-Campo 1977, GómezCampo et al. 2001). The effect of pollinator exclusion was also investigated in these taxa. For the study of $C$. rupestris Porta \& Rigo subsp. leptocarpa (Glez. Albo) Leadlay (classified as "vulnerable" taxon, Bañares et al. 2003), the population in Sierra del Relumbrar was selected. For $C$. longirostra (Boiss.) Greuter \& Burdet (in the "endangered" category, Bañares et al. 2003), the population selected was located in Despeñaperros. For C. monensis (L. Greuter \& Burdet) subsp. orophila (Franco) Aedo, Leadlay \& Muñoz Garm. (unthreatened), we selected the population in Puerto de Niefla. A detailed description of these populations can be found in Gómez-Campo et al. (2001). In all populations mentioned, six plants were enclosed by cages previous to flowering, at the end of February. At the end of May 2001, fruit/flower and seed/ovule ratios were compared between these six enclosed plants and the six plants exposed to pollinators, using the methodology described for $C$. rupestris subsp. rupestris population in MO.

\section{Seedling recruitment and survival of cohorts}

A large rock-ledge in MO was selected on the basis of the following criteria: (i) size and accessibility (ii) soil thickness, (iii) and absence of other ledges over this one in the rock. On 20 September 2000, prior to seedling emergence, ten $1.2 \times 1.2 \mathrm{~m}$ plots were placed at random on the ledge. Plots were divided into four $0.5 \times 0.5 \mathrm{~m}$ subplots separated from each other by $0.2 \mathrm{~m}$, applying one of the following treatments to each one: (a) watering, (b) removal of competitors, (c) watering and removal of competitors, and (d) control (intact subplots). Watering-treatment subplots were watered at the beginning of the experiment and once a month up to the end of the study. Watering doses were $5 \mathrm{~L}$ each time. Therefore, the monthly amount of additional water was 20

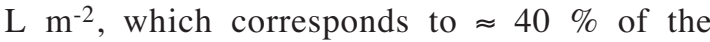
average annual precipitation in the area (648 mm, De León et al. 1988). We added this amount of water to compensate the effects of a 
hypothetical severe drought, i.e., $<60 \%$ of normal rainfall (Beran \& Rodier 1985). Competitors were eliminated by manual ploughing of the entire subplot yearly from the beginning of the experiment. Subplots were checked once a month and emergent seedlings were individually marked by numbered metallic labels which were fixed to the ground surface next to the seedling. This method facilitated seedling monitoring in subsequent visits, and did not affect or modify the interception of light. The presence of flowered plants in 1999 but not in 2000 was observed on the rock-ledge.

The fate of three consecutive cohorts was recorded in plots. Recording periods for each cohort were initiated in October 2000, 2001, and 2002, respectively. All of them finished in January 2003.

\section{Statistical analysis of data}

Data were checked for normality (Cochran test) and homoscedasticity (David test) assumptions prior to performing parametric tests. Data expressed as proportion were previously normalized by root-square arcsin transformation, but untransformed values are shown in tables and figures. Phenological and reproductive parameters were contrasted between both populations studied by Student $\mathrm{t}$ tests. Correlations between phenological and reproductive variables were investigated with a Spearman rank test. The effect of insect exclusion on reproductive success was analysed by two-way ANOVAs, considering "taxon" and "treatment" (i.e., pollinator exclusion versus control) as factors in the analysis of each reproductive variable. When significant main effects existed in a factor with more than two levels, differences were detected by a multiple comparison Tukey test. In the case of significant interactions, if any, differences were explored by contrasting confidence intervals. In the study of seedling emergence, the parameters analysed were: emergent seedlings and seedlings finally established. Two-way ANOVA was also performed for each variable, with "treatment" and "cohort" as factors. We considered the cohort as a factor, in order to detect the annual variability in seedling recruitment, in accordance with our expectations.

\section{RESULTS}

\section{Flower, fruit, and seed production}

Unfortunately, several plants selected for counts were affected by predation (livestock and wild goats, Capra hispanica) to a greater or lesser extent throughout the study (16 in MO and three in $\mathrm{EH}$ ). As a consequence, final data came from 46 intact plants. Apparently, both flower and fruit production were higher in the MO population. However, differences between localities were not significant due to the ample variability in parameters (Table 1). In MO, seeds produced per plant averaged nearly 3,000 and the ratio of fruits/flowers was significantly higher in relation to $\mathrm{EH}$ (Table 1).

TABLE 1

Mean number $( \pm \mathrm{SD})$ of flowers and fruits produced by $C$. rupestris subsp. rupestris in both localities throughout the reproductive period in 2001. Mean values of fruit/flower and seed/fruit ratios are also shown. Parameters were compared between localities; $\mathrm{n}=$ sample size; $\mathrm{t}=$ observed Student $\mathrm{t}$-value for $\mathrm{P}<0.05$ and 44 degrees of freedom; $\mathrm{P}=$ probability of observing the $\mathrm{t}$-value

Número medio $( \pm \mathrm{DE})$ de flores y frutos producidos en 2001 por planta de C.rupestris subsp. rupestris a lo largo de todo el periodo reproductivo en ambas poblaciones. Se muestran los valores medios del número de semillas/fruto y de la razón frutos/flores. Se muestra también la comparación de los parámetros entre localidades; $\mathrm{n}=$ número de réplicas; $\mathrm{t}=\mathrm{valor} \mathrm{t}$ de Student observado para un nivel alfa de 0,05 y 44 grados de libertad; $\mathrm{P}=$ probabilidad de observar el valor de $\mathrm{t}$

\begin{tabular}{lcccc}
\hline & Flowers/plant & Fruits/plant & Fruits/flowers & Seeds/fruit \\
\hline MO $(\mathrm{n}=24)$ & $748.33 \pm 636.0$ & $553.13 \pm 500.8$ & $0.736 \pm 0.14$ & $5.06 \pm 2.4$ \\
EH $(\mathrm{n}=22)$ & $483.23 \pm 688.8$ & $317.59 \pm 518.0$ & $0.610 \pm 0.15$ & $5.06 \pm 2.2$ \\
t-value & 1.357 & 1.567 & 2.903 & 0.009 \\
P-value & 0.182 & 0.124 & 0.006 & 0.993 \\
\hline
\end{tabular}




\section{Flowering phenology}

Estimates of phenological parameters were assessed from plants which completed the reproductive cycle, 15 in each locality. Flowering started between the end of February and early March (Fig. 1). The average duration was 62-63 days (Table 2). The period with the highest flowering (at least $50 \%$ of plants analysed were flowered) extended from middle March to early May in MO, and from the end of March to the end of May in EH (Fig. 1). Hence, there is a time lag between populations, with the flowering occurring earlier in MO.

Curves of flowering were bimodal in both populations, with a pronounced peak in the first week in April and a small one prior to the end of flowering (Fig. 1). The proportion of flowers

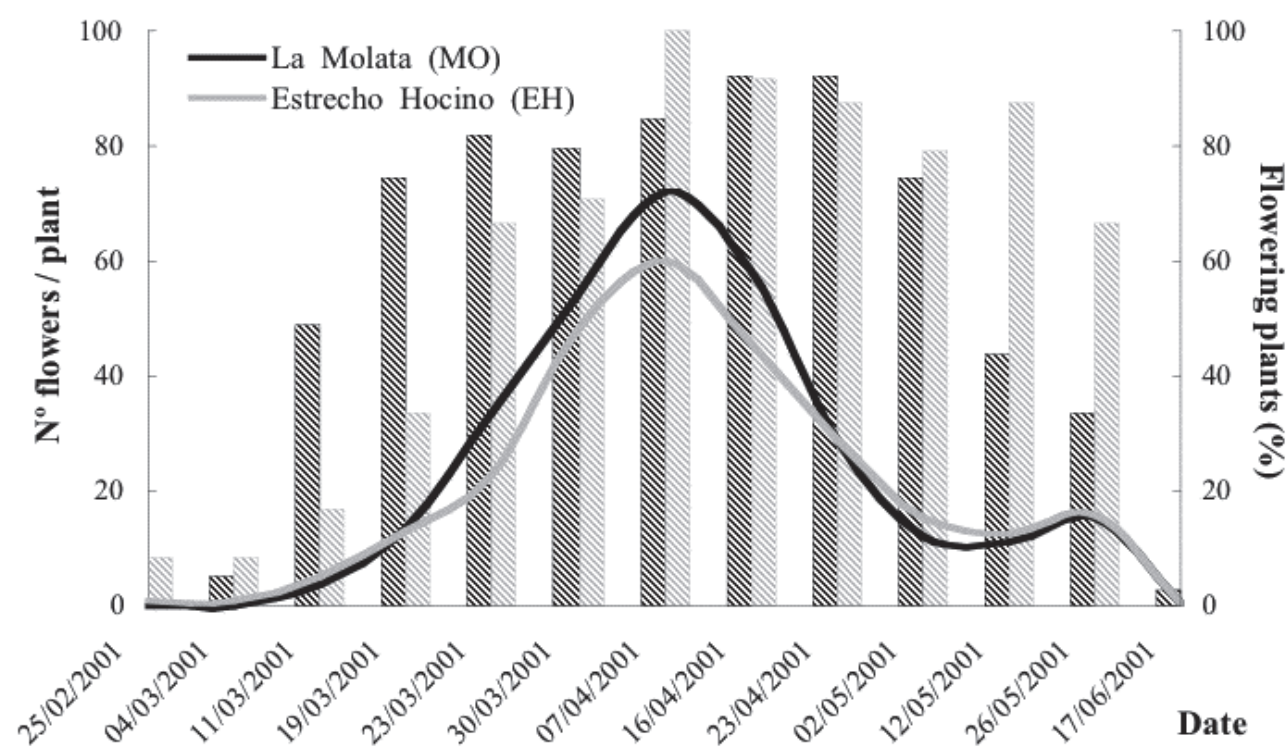

Fig. 1: Flowering phenology of the two C. rupestris subsp. rupestris populations during 2001. Curves show the average number of open flowers per plant. Columns denote the proportion of flowering plants in the population in relation to the whole flowering plants in 2001.

Fenología de la floración de C. rupestris subsp. rupestris durante el año 2001, diferenciando entre las dos poblaciones estudiadas. Las curvas representan el número medio de flores abiertas por planta. Las columnas muestran la proporción de plantas en floración a lo largo del ciclo reproductivo en ambas poblaciones, referida al total de individuos que florecieron este año.

TABLE 2

Mean values $( \pm \mathrm{SD})$ of phenological parameters in C. rupestris subsp. rupestris during 2001. Parameters were compared between both localities; $\mathrm{n}=$ sample size; $\mathrm{t}=$ observed Student $\mathrm{t}$-value for $\mathrm{P}<0.05$ and 28 degrees of freedom; $\mathrm{P}=$ probability of observing the t-value

Valores medios $( \pm \mathrm{DE})$ de las diferentes variables fenológicas de la floración de C. rupestris subsp. rupestris durante 2001. Se muestra también la comparación de parámetros entre localidades; $\mathrm{n}=$ número de réplicas, $\mathrm{t}=$ valor $\mathrm{t}$ de Student observado para un nivel alfa de 0,05 y 28 grados de libertad; $\mathrm{P}=$ probabilidad de observar el valor de $\mathrm{t}$

\begin{tabular}{lcccc}
\hline & Moment (days) & Duration (days) & Intensity (number of flowers) & Synchrony \\
\hline MO $(\mathrm{n}=15)$ & $25.40 \pm 5.93$ & $63.27 \pm 15.47$ & $115.93 \pm 76.24$ & $0.836 \pm 0.08$ \\
EH $(\mathrm{n}=15)$ & $26.80 \pm 15.10$ & $62.00 \pm 18.30$ & $62.73 \pm 53.80$ & $0.862 \pm 0.12$ \\
t-avalue & -0.334 & 0.205 & 2.208 & -0.691 \\
P-value & 0.741 & 0.839 & 0.036 & 0.495 \\
\hline
\end{tabular}


aborted showed an increase throughout the flowering period, achieving the absolute maximum in mid-May in MO (29.29\%) and mid-June in EH (44.13\%). Significant differences were only detected in the flowering intensity, being two-fold higher in MO than in EH. As shown in Table 2, all the other variables are quite close in both populations.

In both localities, there was a marked autocorrelation both between certain reproductive variables and between certain phenological variables. Indeed, fruit number and flower number were positively correlated, whereas duration and synchrony showed negative correlation (Table 3 ). Thus, the longer the flowering period in a plant, the lower the overlap with flowering of other plants. Relationships between both groups of variables were also evidenced in the correlation analysis: intensity was positively correlated with both flower number and with fruit number (Table 3 ). Although weaker, additional correlations were detected in $\mathrm{EH}$, with a significant negative correlation between synchrony and both flower and fruit number (Table 3 ).

\section{Reproductive success and the role of pollinator insects}

Exclusion of insects dramatically affected fruit ripening of $C$. rupestris subsp. rupestris, reducing the number of fertile fruits to nearly null values, as shown by comparisons between enclosed and free-caged plants (Table 4).
Furthermore, the few fruits ripening within cages produced few seeds (Fig. 2).

In the other Coincya taxa tested, the effect of insect exclusion was similar, also severely reducing reproductive success: significant main effects due to treatment (exclusion vs. control) were detected for fruit/flower ratio and reproductive success (Table 4 ). The reproductive success in Coincya genus did not decline with the increase in threat level of taxa: no significant main effect was manifested when contrasting variables among taxa (Table 4). The values of fruit/flower ratio recorded in Coincya taxa other than $C$.rupestris subsp. rupestris were similar to those in $C$. rupestris subsp. rupestris, ranging from $0.447 \pm 0.075$ to $0.667 \pm 0.095$ (Table 4$)$.

\section{Seedling recruitment}

In the two variables analysed, only significant main effects in the cohort factor were detected; the treatment applied to subplots neither significantly affects the number of emergent seedlings, nor the final juvenile density. Twoway ANOVAs did not reveal significant interactions in any case (Table 5).

Seedling emergence occurred in autumn. The largest cohort corresponded to 2001-2002, much more numerous than in 2002-2003, and without significant differences in relation to 2000-2001. The 2000-2001 cohort produced the highest number of juveniles (1 year old), since mortality was lower than in the 2001-2002 cohort (Fig. 3, Table 5).

TABLE 3

Spearman correlation coefficients between phenological and reproductive parameters. Values over the diagonal correspond to $\mathrm{MO}$ population, and those under the diagonal correspond to $\mathrm{EH}$ one; * $\mathrm{P}$

$$
<0.05 ; * * \mathrm{P}<0.01
$$

Coeficientes de correlación de Spearman entre las variables fenológicas y las variables reproductivas. Los valores por encima de la diagonal corresponden a la población MO y los valores por debajo corresponden a $\mathrm{EH} ; * \mathrm{P}<0,05 ; * * \mathrm{P}<0,01$

\begin{tabular}{lccccccc}
\hline & Moment & Duration & Intensity & Synchrony & Flowers & Fruits & Fruits/flowers \\
\hline Moment & & 0.387 & 0.376 & -0.241 & 0.068 & 0.269 & 0.177 \\
Duration & 0.220 & & 0.408 & $-0.945^{* *}$ & 0.338 & 0.334 & -0.101 \\
Intensity & 0.161 & $0.612^{*}$ & & -0.308 & $0.781^{* *}$ & $0.898^{* *}$ & -0.036 \\
Synchrony & -0.078 & $-0.770^{* *}$ & -0.461 & & -0.199 & -0.200 & -0.018 \\
Flowers & 0.215 & $0.599^{*}$ & $0.736^{* *}$ & $-0.674^{*}$ & & $0.895^{* *}$ & -0.454 \\
Fruits & 0.240 & $0.537^{*}$ & $0.781^{* *}$ & $-0.618^{*}$ & $0.954^{* *}$ & & -0.064 \\
Fruits/flowers & -0.153 & -0.234 & 0.311 & 0.130 & 0.100 & 0.236 &
\end{tabular}


TABLE 4

Reproductive success (mean $\pm \mathrm{SD}$ ) in Coincya taxa with and without pollinators

Éxito reproductivo (media \pm DE) en Coincya con presencia y ausencia de polinizadores

\begin{tabular}{|c|c|c|c|c|c|c|}
\hline & \multicolumn{3}{|c|}{ With pollinators } & \multicolumn{3}{|c|}{ Without pollinators } \\
\hline & Fruits / flowers & Seeds / ovules & $\begin{array}{c}\text { Reproductive } \\
\text { success }\end{array}$ & Fruits / flowers & Seeds / ovules & $\begin{array}{l}\text { Reproductive } \\
\text { success }\end{array}$ \\
\hline $\begin{array}{l}\text { C. rupestris } \\
\text { subsp. rupestris }\end{array}$ & $0.551 \pm 0.189$ & $0.945 \pm 0.081$ & $0.512 \pm 0.154$ & $0.021 \pm 0.027 *$ & $0.738 \pm 0.412$ & $0.015 \pm 0.023 *$ \\
\hline $\begin{array}{l}\text { C. rupestris } \\
\text { subsp. leptocarpa }\end{array}$ & $0.587 \pm 0.061$ & $0.863 \pm 0.083$ & $0.505 \pm 0.056$ & $0.000 \pm 0.000 *$ & - & $0.000 \pm 0.000 *$ \\
\hline C. longirostra & $0.447 \pm 0.075$ & $0.821 \pm 0.128$ & $0.358 \pm 0.024$ & $0.049 \pm 0.052^{*}$ & $0.551 \pm 0.250$ & $0.027 \pm 0.038^{*}$ \\
\hline $\begin{array}{l}\text { C. monensis } \\
\text { subsp. orophila }\end{array}$ & $0.667 \pm 0.095$ & $0.918 \pm 0.063$ & $0.615 \pm 0.113$ & $0.032 \pm 0.035^{*}$ & $0.639 \pm 0.311$ & $0.020 \pm 0.018^{*}$ \\
\hline
\end{tabular}

* Denotes significant reduction due to the insect exclusion, detected by contrasting confidence intervals with control treatments

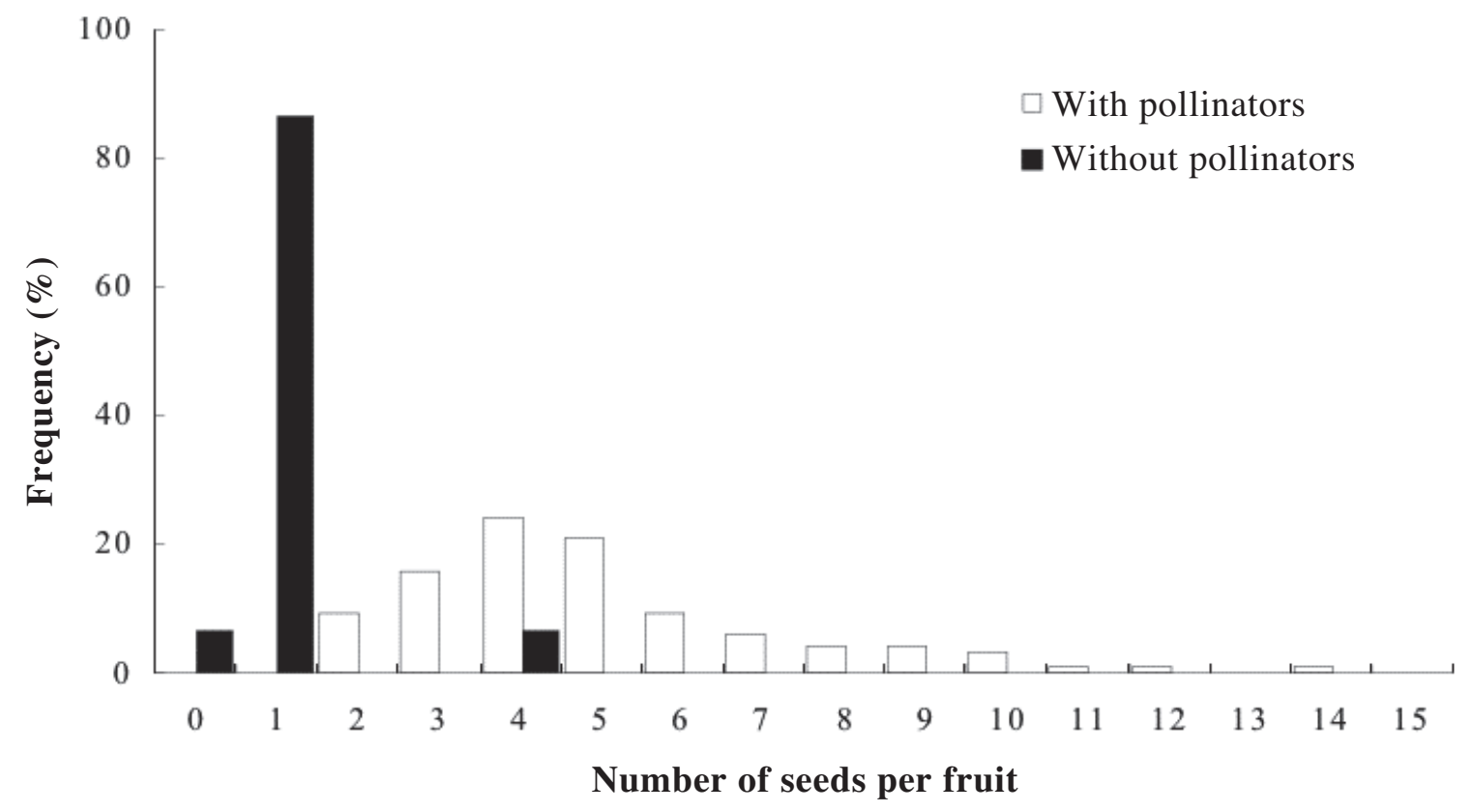

Fig. 2: Histogram of seed number contained in siliquas of $C$. rupestris subsp. rupestris. Values from cage-enclosed $(n=15)$ and insect-exposed $(n=96)$ plants are shown separately. The small sample size for enclosed plants was due to the low fruit production.

Histograma de frecuencias del número de semillas contenido en las silicuas de C. rupestris subsp. rupestris, diferenciando entre plantas con libre acceso a insectos polinizadores $(n=96)$ y de plantas con exclusión de los mismos $(n=15)$. El tamaño muestral del grupo con exclusión fue reducido debido al exiguo número de frutos producidos.

The initial size of the cohort was not related to autumn rainfall in that year. Indeed, autumn 2000 was rainier than the autumn of 2001 (245 $\mathrm{mm}$ versus $170 \mathrm{~mm}$, respectively). However, more seedlings germinated during the latter (Fig. 3).
Although some seedlings which emerged during autumn 2000 reached the adult stage (1.5 plants $\mathrm{m}^{-2} ; 4.16 \%$ of seedlings), and dispersed seeds in spring 2002, seedling emergence in autumn 2002 was the lowest during the study. 


\section{TABLE 5}

Mean density $( \pm \mathrm{SD})$ of $C$. rupestris subsp. rupestris emergent seedlings and juveniles established (1 year old) in each treatment and cohort. Data from 2002-2003 are not shown for juveniles due to the small cohort size and the short period of the study

Densidad media ( \pm DE) de plántulas de $C$. rupestris subsp. rupestris emergidas y de juveniles establecidos (1 año de edad) para cada tratamiento y cohorte. No se muestran datos de 2002-2003 para juveniles debido al pequeño tamaño de esta cohorte, y al corto periodo estudiado

\begin{tabular}{|c|c|c|c|c|}
\hline & \multicolumn{4}{|c|}{ Seedlings (seedlings $\mathrm{m}^{-2}$ ) } \\
\hline & Control & Watering & No competition & No competition + watering \\
\hline $2000-2001$ & $46.40 \pm 18.77$ & $38.40 \pm 9.80$ & $28.40 \pm 8.48$ & $44.80 \pm 15.05$ \\
\hline 2001-2002 & $68.00 \pm 16.76$ & $70.40 \pm 27.24$ & $42.40 \pm 13.56$ & $70.40 \pm 23.26$ \\
\hline \multirow[t]{3}{*}{$2002-2003$} & $3.60 \pm 2.42$ & $2.80 \pm 1.58$ & $0.40 \pm 0.40$ & $0.00 \pm 0.00$ \\
\hline & \multicolumn{4}{|c|}{ Juveniles (juveniles $\mathrm{m}^{-2}$ ) } \\
\hline & Control & Watering & No competition & No competition + watering \\
\hline $2000-2001$ & $14.80 \pm 7.11$ & $8.00 \pm 3.77$ & $8.80 \pm 2.91$ & $14.00 \pm 3.74$ \\
\hline 2001-2002 & $11.60 \pm 4.67$ & $4.00 \pm 1.98$ & $4.40 \pm 1.83$ & $2.00 \pm 1.07$ \\
\hline
\end{tabular}

\section{DISCUSSION}

\section{Flower, fruit, and seed production}

The high values of flower, fruit, and seed production recorded in the study suggest that the rarity of $C$.rupestris subsp. rupestris is not determined by restrictions in fecundity. In addition, studies in different years showed high values of seed viability, ranging between 90 and $95 \%$ (Herranz et al. 2003, Copete et al. 2005). As pointed out by Torres et al. (2002) for another threatened species, Antirrhinum microphyllum, abundant seed production should lead to rejection of low fertility as the cause of population decline. However, C. rupestris subsp. rupestris has the lowest seed/fruit ratio (5.06) when compared with the other Coincya taxa. Gómez-Campo et al. (2001) assessed the following seed/fruit ratio values when analysing the same populations considered in the present study: 11.54 in $C$. rupestris subsp. leptocarpa, 17.98 in C. longirostra, and 30.71 in C. monensis subsp. orophila. This record is in accordance with the generally accepted hypothesis that broadly distributed species tend to produce higher seed yield than the corresponding taxonomically-related species with restricted distribution (Fiedler 1987).

Although differences in flower and fruit production were not detected between localities, flowering started earlier in MO. Other studies have suggested that such fitness components increase markedly in earlyflowering plants (Giménez-Benavides et al. 2007).

\section{Flowering phenology}

The high synchrony of flowering registered in both populations studied $(\approx 85 \%)$ should allow plants to cross pollen and thus genes, so the effective population size may be close to the actual one (Augspurger 1981). This is especially relevant in allogamous selfincompatible plant species with small populations, such as $C$. rupestris subsp. rupestris. The flowering period extended over three months, from weeks in late winter to the end of spring. This may be considered as an adaptive advantage in Mediterranean ecosystems, where water stress as summer approaches would restrict reproductive success of late-flowering plants (Johnson 1992). In fact, such a phenological pattern in $C$. rupestris subsp. rupestris would be advantageous, in adaptive terms, if compared with the other Coincya taxa, which flower 2-3 weeks later. This advantage should be added to those proposed for $C$. rupestris subsp. rupestris by Gómez-Campo et al. (2001) after a morphological analysis of fruits in the four taxa. 

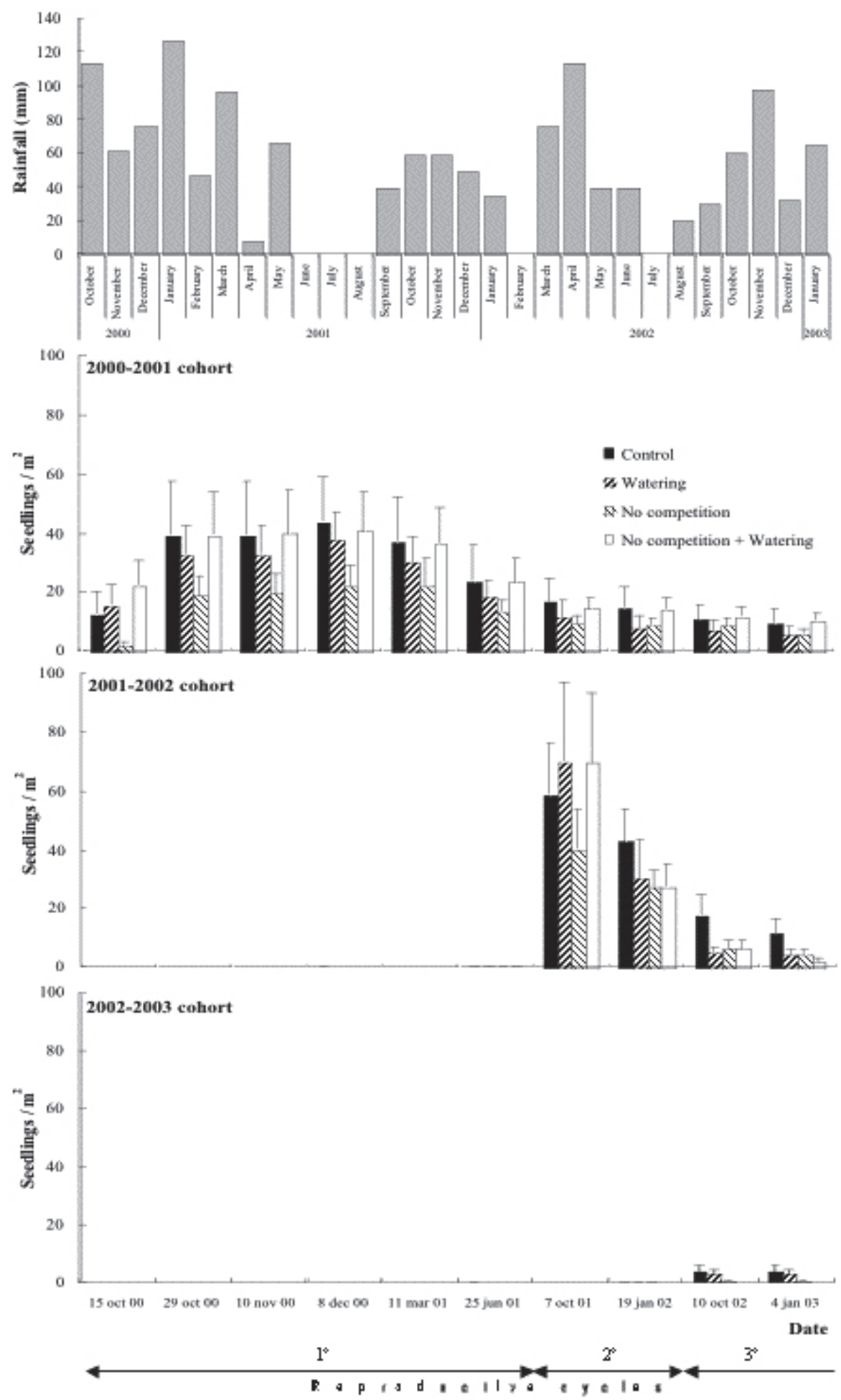

Fig. 3: Changes in the mean density (seedlings $\mathrm{m}^{-2}$ ) of three cohorts of $C$. rupestris subsp. rupestris seedlings after four treatments applied in MO during autumn 2000. Bars on columns represent the standard error. The upper diagram shows rainfall during the study.

Variación de la densidad media (plántulas $\mathrm{m}^{-2}$ ) de tres cohortes de plántulas de C. rupestris subsp. rupestris en MO en función de cuatro tratamientos aplicados durante el otoño de 2000. Las barras verticales representan el error estándar correspondiente. El histograma superior representa la precipitación durante el estudio. 
In $\mathrm{MO}$, flowering started 15 days earlier than in $\mathrm{EH}$, which is remarkable considering the higher altitude of the former, which should determine colder winter conditions. Cold periods affecting the basal rosette produced in the first year may be positively correlated with flowering precocity, as recorded by Nordborg \& Bergelson (1999) in another crucifer, Arabidopsis thaliana.

As regards phenological parameters, only flowering intensity showed significant interpopulation differences. Higher intensity values recorded in MO may be due to the more conspicuous flowering in this locality, although the number of flowers did not differ significantly between the two localities. The positive correlation described between flower production and intensity (Iriondo et al. 1998), along with more suitable environmental conditions for the taxon in MO, would explain such differences.

The strong positive correlation between the number of flowers and number of fruits detected in both $C$. rupestris subsp. rupestris populations has also been detected in other threatened rupicolous species, such as Erodium paularense (Albert et al. 2001) and Antirrhinum microphyllum (Torres et al. 2002). On the other hand, the negative correlation between duration and synchrony may result in a deficient cross pollination during some phases of the long flowering period, and thus in a decline in reproductive success. However, GiménezBenavides et al. (2007) found that duration had a significant positive effect on flowering synchrony in Silene ciliata Poiret, another Mediterranean mountain plant. No correlation was found between synchrony and fruit/flower ratio: neither positive, which may be expected from the increase in pollen availability and allogamous pollination as a result of synchrony (Moeller 2004); nor negative, as a consequence of a hypothetic reduction in the number of pollinators per plant (Zimmerman 1980, Giménez-Benavides et al. 2007).

\section{Reproductive success}

The presence of a genetic mechanism of selfincompatibility, described by Leadlay \& Heywood (1990) in Coincya species, explains why the exclusion of pollinator insects drastically reduced fruit ripening and seed/ovule ratio, resulting in a nearly null reproductive success. Experiments in self-pollination carried out by these authors in $C$. rupestris subsp. rupestris only succeeded by $17 \%$ and seed production was reduced to a third in comparison with cross-pollinated plants. The production of some fruit in our experiment may be due to the entrance of small insects (e.g., ants, tiny beetles) into the cage, and also by self-pollination mechanisms, which are unusual but confirmed by Leadlay \& Heywood (1990) in Coincya, and frequent in allogamous species (Schemske \& Lande 1985). A reduction in fruit and seed production due to pollen exclusion has also been recorded in many other rare or threatened species such as Silene spaldingii (Lesica 1994) and Silene regia (Menges 1995). Lesica (1994) pointed out that the offspring originated by selffertilization when pollinator vectors are excluded can suffer inbreeding depression, proportional to the degree of allogamy. Inbreeding depression can manifest itself in any phase of the life cycle as a reduction of fitness: lower germination, survival and growth of seedlings. The detrimental effects due to a reduction in reproductive success when pollinators are excluded, along with the consanguinity of the offspring originated by autogamy, may even be amplified in small populations such as those of $C$. rupestris subsp. rupestris, where the degree of relationship may be high (Barret \& Kohn 1991).

In insect-pollinated Aconitum and Delphinium species, Bosch \& Waser (1999) found a positive correlation between population density and fruit production due to changes both in quantitative and qualitative pollen traits: the higher the plant population size, the higher the amount and genetic variability of pollen. Neel et al. (2001) emphasized the importance of maintaining sufficiently large plant populations in order to conserve insects involved in cross-pollination, thus reducing the inbreeding-depression risk. Such risk is also enhanced in small plant populations due to the higher probability of geitonogamous pollination (Menges 1991). When plants were exposed to pollinators, neither the reproductive success nor fruit/flower ratio declined with the degree of threat in the Coincya taxa analysed, and thus with the population size. This may prove that even in small $C$. rupestris subsp. rupestris populations, the activity of insect 
pollinators is high enough to guarantee reproductive success, contrasting with records in other species (Horvitz \& Schemske 1988, Burd 1994). This conclusion is also supported by the lack of correlation between the intensity of flowering and the fruit/flower ratio, since it would evidence that an increase in the activity of insects associated with higher flower availability did not enhance fruit production. Nevertheless, the role of insects should not be undervalued in the maintenance of $C$. rupestris subsp. rupestris populations, even though it was not limiting.

\section{Seedling recruitment}

Since flowering did not take place in 2000 and 2001 on the rock-ledge selected for the study, seedlings emerging during these years could have three possible sources: (i) the soil seed bank, (ii) seeds retained in the beak, the indehiscent portion of the siliqua, and (iii) wind-dispersed seeds coming from surrounding zones. The soil seed bank was described as short-term persistent ( $2-5$ years, 175 seeds $\mathrm{m}^{-2}$ ) from the analysis of samples collected in this locality (Herranz et al. 2003). In C. rupestris subsp. rupestris, the beak contains more seeds than the valvar portion (Gómez-Campo et al. 2001), and they are released when beak walls disintegrate, taking several months (Copete et al. 2005). In addition, beak seeds are bigger than valvar seeds (Herranz et al. 2003), making beak seeds more capable of producing seedlings likely to survive (Baskin \& Baskin 1998). The arrival of wind-dispersed seeds is improbable since there was no rock-ledge above the one selected for the study and adaptations for wind seed dispersal (i.e., beak enlarged) are little effective. Therefore, the importance of the first two mechanisms should be emphasized, because they would guarantee the establishment of seedlings for at least two years, even though there was no in-site seed production. This point is crucial to the persistence of a threatened taxon and these mechanisms may therefore explain the interannual broad fluctuations recorded in population size of $C$. rupestris subsp. rupestris (Domínguez et al. 1996, Copete 2005).

The higher mortality recorded in the cohort originating in 2001 may be due to the lower rainfall of that year in comparison with the previous autumn, although the initial emergence was higher. The lack of significant effects of treatments on seedling emergence and seedling establishment showed that the watering doses and the initial elimination of competition were not determinants. A possible reason for the lack of significant effects of the watering factor may be that the rainfall during the study period was lower than mean values (annual deficits of $1.9,19.3$ and $10.7 \%$, respectively) but far from the severe drought limit, established at $40 \%$ (Beran \& Rodier 1985). However, similar watering doses during warm periods and repeated removal of competitors may result in significant influence. Future analyses could apply more intense treatments.

\section{Recommendations for management}

The present study analyzes several reproductive biology features of the critically endangered plant $C$. rupestris subsp. rupestris. The results show that (i) the taxon has high fecundity (i.e., high capability to produce flowers, fruits, and seeds); (ii) reproductive success does not correspond to the degree of taxon threat within the genus; and (iii) inter-specific competition and water availability during the seedling establishment stage, within the normal range in the natural habitat, would not be limiting factors for the recruitment of new individuals. However, recruitment can amply oscillate from year to year, which may lead $C$. rupestris subsp. rupestris populations to be critically vulnerable to external impacts during unfavorable years. Indeed, the regional Government has recently forbidden climbing activities in the two localities (Decree 29/2003 in DOCM (2003), and Decree 321/2003 in DOCM (2004)), due to detrimental effects observed on rock ledges inhabited by the taxon. Legal banning, however, should be extended to any other activity causing detrimental impacts to rock ledges and bases of rocky walls currently occupied by the taxon or forming potential habitat. Grazing and trampling associated with trekking and recreational walks have been detected in both localities. The protection of potential habitat should be stressed. Previous studies have shown that $C$. rupestris subsp. rupestris has the ability to form short-term persistent seed banks in the 
soil (Herranz et al. 2003). This trait, along with the high reproductive potential evidenced in the present study, should allow the plant to occupy zones within its natural area if impacts cease.

The important role of pollinator insects in ensuring the reproductive success of $C$. rupestris subsp. rupestris emphasizes the necessity of conserving their populations. The use of insecticides should be forbidden in the habitat of the plant and also in agricultural areas near the localities studied. In fact, the preliminary results of this study promoted the legal ban of pesticide use in the micro-reserves of MO and EH (Decrees 29/2003 and 321/ 2003) by the regional Government of CastillaLa Mancha. We strongly recommend extending restrictions in the use of phytochemicals to surrounding influential areas as well.

\section{ACKNOWLEDGEMENTS}

This study received financial support from the regional Government of Castilla-La Mancha (project "Estudio de aspectos de la biología poblacional y reproductiva de 10 especies vegetales amenazadas de Castilla-La Mancha") and the Spanish Government (Plan Nacional I+D, Ministerio de Educación y Ciencia; Ref. CGL2004-00819/BOS). M.A. Copete also received a grant from the Government of Castilla-La Mancha (Consejería de Educación y Ciencia) in order to complete the study. Authors are grateful to Juan José Martínez-Sánchez and José Antonio Franco for their useful comments on a draft version of the manuscript, and to Kathryn Walsh for checking the English. Three anonymous reviewers contributed to enhancing the quality of the manuscript.

\section{LITERATURE CITED}

ALBERT MJ, A ESCUDERO \& JM IRIONDO (2001) Female reproductive success of narrow endemic Erodium paularense in contrasting microhabitats. Ecology 82: 1734-1747

AUGSPURGER CK (1981) Reproductive synchrony of a tropical shrub: experimental studies on effects of pollinators and seed predators on Hybanthus prunifolius (Violaceae). Ecology 63: 775-788.

BAÑARES A, G BLANCA, J GÜEMES, JC MORENO \& S ORTIZ (2003) Atlas y libro rojo de la flora vascular amenazada de España. Dirección General de Conservación de la Naturaleza, Madrid, España. $1,069 \mathrm{pp}$.
BARRET SCH \& JR KOHN (1991) Genetic and evolutionary consequences of small population size in plants: implications for conservation. In: Falk DA \& KE Holsinger (eds) Genetics and conservation in rare plants: 3-30. Oxford University Press, New York, USA.

BASKIN CC \& JM BASKIN (1998) Seeds ecology, biogeography and evolution of dormancy and germination. Academic Press, San Diego, California, USA. $666 \mathrm{pp}$

BERAN M \& JA RODIER (1985) Hydrological aspects of drought. Studies and reports in hydrology 39. UNESCO-WMO, Paris, France. 149 pp.

BOE (1990) Real Decreto 439/1990, de 30 de marzo, por el que se regula el catálogo nacional de especies amenazadas. Boletín Oficial del Estado (Spain) 82: 9468-9471.

BOSCH M \& M WASER (1999) Effects of local density on pollination and reproduction in Delphinium nuttallianum and Aconitum columbianum (Ranunculaceae). American Journal of Botany 86: 871-879.

BURD M (1994) Baterman's principle and plant reproduction: the role of pollen limitation in fruit and seed set. Botanical Review 60: 83-139.

CASTROVIEJO S (1993) Flora ibérica. Plantas vasculares de la Península Ibérica e Islas Baleares. Real Jardín Botánico, CSIC, Madrid, Spain. 730 pp.

CHARLESWORTH D (1989) Evolution of low female fertility in plants: pollen limitation, resource allocation and genetic load. Trends in Ecology and Evolution 4: 289-292.

CONNER JK \& S RUSH (1996) Effects of flower size and number on pollinator visitation to wild radish, Raphanus raphanistrum. Oecologia 105: 509-516.

COPETE MA (2005) Aspectos de la biología poblacional y reproductiva de las especies vegetales amenazadas Helianthemum polygonoides, Coincya rupestris subsp. rupestris, Sideritis serrata y Sisymbrium cavanillesianum. Doctoral thesis, Universidad de Castilla-La Mancha, Madrid, Spain. 276 pp.

COPETE MA, JM HERRANZ \& P FERRANDIS (2005) Seed dormancy and germination in threatened Iberian Coincya (Brassicaceae) taxa. Ecoscience 12: 257-266.

DE LEÓN A, A ARRIBA \& MC DE LA PLAZA (1988) Caracterización agroclimática de la provincia de Albacete. Ministerio de Agricultura, Pesca y Alimentación, Madrid, Spain. 183 pp.

DE MAURO MM (1993) Relationship of breeding system to rarity in the lakeside daisy (Hymenoxys acaulis var. glabra). Conservation Biology 7: 542-550.

DE MAURO MM (1994) Development and implementation of a recovery program for the federal threatened Lakeside daisy (Hymenoxys acaulis var. glabra). In: Bowles ML \& CJ Whelan (eds) Restoration of endangered species. Conceptual issues, planning and implementation: 298-321. Cambridge University Press, Cambridge, United Kingdom.

DOCM (1999) Decreto 237/1999, de 14 de diciembre, por el que se aprueba el Plan de Recuperación de la especie de flora Coincya rupestris y se inicia el procedimiento de declaración de las microrreservas del Estrecho del Hocino y de La Molata (Albacete). Diario Oficial de Castilla, La Mancha (Spain) 83: 10520-10523.

DOCM (2003) Decreto 29/2003, de 18 de marzo, por el que se declara como microrreserva al paraje conocido como La Molata y Los Batanes (Alcaraz, Albacete). Diario Oficial de Castilla, La Mancha (Spain) 46: 5041-5044 
DOCM (2004) Decreto 321/2003, de 23 de diciembre, por el que se declara como microrreserva al paraje conocido como Estrecho del Hocino (Salobre, Albacete). Diario Oficial de Castilla, La Mancha (Spain) 12: 1430-1432.

DOMÍNGUEZ F, D GALICIA, L MORENO, JC MORENO \& H SAINZ-OLLERO (1996) Threatened plants in peninsular and Balearic Spain: a report base on the EU Habitat Directive. Biological Conservation 76: 123-133.

EVANS MEK, RW DOLAN, ES MENGES \& DR GORDON (2000) Genetic diversity and reproductive biology in Warea carteri (Brassicaceae), a narrowly endemic Florida scrub annual. American Journal of Botany 87: 372-381.

EVANS MEK, ES MENGES \& DR GORDON (2003) Reproductive biology of three sympatric endangered plants endemic to Florida scrub. Biological Conservation 111: 235-246.

FACEY P, P LEE, M SMITH \& C HIPKIN (2007) Conservation of genetic diversity in British populations of the diploid endemic Coincya monensis ssp. monensis (Isle of Man Cabbage): the risk of hybridisation with the tetraploid alien, Coincya monensis ssp. cheiranthos. Conservation Genetics 8: 1029-1042.

FIEDLER PL (1987) Life history and population dynamics of rare and common mariposa lilies (Calochortus Pursh: Liliaceae). Journal of Ecology 75: 977-995.

FULCO L, H DE KROON, HHT PRINS \& F BERENDSE (2001) Effects of nutrients and shade on tree-grass interactions in an east African savannah. Journal of Vegetation Science 12: 579-588.

GARCÍA-FAYOS P, B GARCÍA-VENTOSO \& A CERDÀ (2000) Limitations to plant establishment on eroded slopes in southeastern Spain. Journal of Vegetation Sciences 11: 77-86.

GIMÉNEZ-BENAVIDES L, A ESCUDERO \& JM IRIONDO (2007) Reproductive limits of a lateflowering high-mountain Mediterranean plant along an elevational climate gradient. New Phytologist 173: 367-382.

GÓMEZ-CAMPO C (1977) Clinal variation and evolution in the Hutera-Rhynchosinapis complex of the Sierra Morena (south-central Spain). Botanical Journal of the Linnean Society 75: 179-194.

GÓMEZ-CAMPO C (1999) Biology of Brassica coenospecies. Elsevier, Amsterdam, The Netherlands. 489 pp.

GÓMEZ-CAMPO C, JM HERRANZ \& F MONTERO (2001) The genus Coincya Rouy (Cruciferae) in south-central Spain revisited: a morphometric analysis of population structure. Botanical Journal of the Linnean Society 135: 125-135.

GUITIÁN J \& JM SÁNCHEZ (1992) Flowering phenology and fruit set of Petrocoptis grandiflora (Caryophyllaceae). International Journal of Plant Sciences 153: 409-412.

HERRANZ JM, P FERRANDIS \& MA COPETE (2003) Influence of temperature, maternal source, and seed position in fruit on seed germination and ability to form soil seed banks in threatened species of Coincya (Cruciferae). Israel Journal of Plant Sciences 51: 133-141.

HERRANZ JM, MA COPETE \& P FERRANDIS (2004) Distribución geográfica, demografía y ecología de la crucífera amenazada Coincya rupestris Porta \& Rigo ex Rouy subsp. leptocarpa (Gonz.-Albo) Leadlay. Ecología (Spain) 18: 81-98.

HORVITZ CC \& DW SCHEMSKE (1988) A test of the pollinator limitation hypothesis for a Neotropical herb. Ecology 69: 200-206.

IRIONDO JM, E TORRES, A ESCUDERO, M GRIS, ME GONZÁLEZ-BENITO \& C PÉREZ (1998) Propuesta del plan de recuperación de Antirrhinum microphyllum Roth. Unpublished report. Junta de Comunidades de Castilla-La Mancha, Madrid, Spain. 48 pp.

IUCN, International Union for the Conservation of Nature (2001) IUCN red list categories and criteria. Version 3.1. IUCN Species Survival Comision, Gland, Switzerland. $30 \mathrm{pp}$

IZCO J (2004) Botánica. Second edition. McGraw-Hill Interamericana, Aravaca, Madrid, Spain. 920 pp.

JOHNSON SD (1992) Climatic and phylogenetic determinants of flowering seasonality in the Cape flora. Journal of Ecology 81: 567-572.

KEARNS CA \& DW INOUYE (1993) Techniques for pollination biologists. University Press of Colorado, Niwot, Colorado, USA. 583 pp.

KELLY CA (1992) Reproductive phenologies in Lobelia inflata (Lobeliaceae) and their environmental control. American Journal of Botany 79: 11261133.

KELLY CA (1993) Quantitative genetics of size and phenology of life-history traits in Chamaecrista fasciculata. Evolution 47: 88-97.

LEADLAY EA \& VH HEYWOOD (1990) The biology and systematics of the genus Coincya Porta \& Rigo ex Rouy (Cruciferae). Botanical Journal of the Linnean Society 102: 313-398.

LESICA P (1994) Loss of fitness resulting from pollinator exclusion in Silene spaldingii (Caryophyllaceae). Madroño (Spain) 40: 193-201.

LLORET F, J PEÑUELAS \& M ESTIARTE (2005) Effects of vegetation canopy and climate on seedling establishment in Mediterranean shrubland. Journal of Vegetation Science 16: 67-76.

LORNE MW \& JL BURNS (2001) A rare continual flowering strategy and its influence on offspring quality in a gynodioecious plant. American Journal of Botany 88: 1419-1423.

MAZER SJ \& LM WOLFE (1998) Density-mediated maternal effects on seed size in wild radish: genetic variation and its evolutionary consequences. In: Mousseau TA \& CW Fox (eds) Maternal effects as adaptations: 323-343. Oxford University Press, New York, USA.

MENGES ES (1991) Seed germination percentage increases with population size in a fragmented prairie species. Conservation Biology 5: 158-164.

MENGES ES (1995) Factors limiting fecundity and germination in small populations of Silene regia (Caryophyllaceae), a rare hummingbird-pollinated prairie forb. American Midland Naturalist 133: 242255.

MOELLER DA (2004) Facilitative interactions among plants via shared pollinators. Ecology 85: 32893301.

NEEL MC, J ROSS-IBARRA \& NC ELLSTRAND (2001) Implications of mating patterns for conservation of the endangered plant Eriogonum ovalifolium var. vineum (Polygonaceae). American Journal of Botany 88: 1214-1222.

NIKLAS KJ (1994) Plant allometry: the scaling of form and process. University of Chicago Press, Chicago, Illinois, USA. $412 \mathrm{pp}$

NORDBORG M \& J BERGELSON (1999) The effect of seed and rosette cold treatment on germination and flowering time in some Arabidopsis thaliana 
(Brassicaceae) ecotypes. American Journal of Botany 86: 470-475.

OLLERTON J \& A LACK (1992) Flowering phenology: an example of relaxation of natural selection Trends in Ecology and Evolution 7: 274-278

PEÑUELAS J \& I FILELLA (2003) Deuterium labelling of roots provides evidences of deep water access and hydraulic lift by Pinus nigra in a Mediterranean forest of NE Spain. Environmental and Experimental Botany 43: 201-208.

PUGNAIRE FI, ARMAS C \& VALLADARES F (2004) Soil as a mediator in plant-plant interactions in a semi-arid community. Journal of Vegetation Sciences 15: 85-92.

REY P \& J ALCÁNTARA (2000) Recruitment dynamics of a fleshy-fruited plant (Olea europaea): connecting patterns of seed dispersal to seedling establishment. Journal of Ecology 88: 622-633.

RODRÍGUEZ-PÉREZ J (2005) Breeding system, flower visitors and seedling survival of two endangered species of Helianthemum (Cistaceae). Annals of Botany 95: 1229-1236.

SÁNCHEZ AM \& B PECO (2004) Interference between perennial grassland and Lavandula stoechas subsp. pedunculata seedlings: a case of spatial segregation caused by competition. Acta Oecologica 26: 39-44.

SCHEMSKE DW \& R LANDE (1985) The evolution of self-fertilization and inbreeding depression in plants. II. Empirical observations. Evolution 39: 4152.

SYNGE H (ed) (1981). The biological aspects of rare plant conservation. Wiley, Chichester, New York, USA. $558 \mathrm{pp}$.

THÉBAUD C, AC FINZI, L AFFRE, M DEBUSSCHE \& J ESCARRÉ (1996) Assessing why two introduced Conyza differ in their ability to invade Mediterranean old fields. Ecology 77: 791-804.

TORRES E，JM IRIONDO \& C PÉREZ (2002)
Vulnerability and determinants of reproductive success in the narrow endemic Antirrhinum microphyllum (Scrophulariaceae). American Journal of Botany 89: 1171-1179.

TRAVESET A, J GULIAS, N RIERA \& M MUS (2003) Transition probabilities from pollination to establishment in a rare deciduous shrub species (Rhamnus ludovici-salvatoris) in two habitats. Journal of Ecology 91: 427-437.

TYLER CM \& CM D'ANTONIO (1995) The effects of neighbors on the growth and survival of shrub seedlings following fire. Oecologia 102: 255-264.

VALLADARES F \& RW PEARCY (2002) Drought can be more critical in the shade than in the sun: a field study of carbon gain and photo-inhibition in a Californian shrub during a dry El Niño year. Plant Cell Environment 25: 749-759.

VIOQUE J, JE PASTOR, M ALAIZ \& E VIOQUE (1994) Chemotaxonomic study of seed glucosinolate composition in Coincya Rouy (Brassicaceae). Botanical Journal of the Linnean Society 116: 343350

WALCK JR, JM BASKIN \& CC BASKIN (1999) Ecology of the endangered species Solidago shortii. VI. Effects of habitat type, leaf litter, and soil type on seed germination. Journal of the Torrey Botanical Society 126: 117-123.

WELLER SG (1994) The relationship of rarity to plant reproductive biology. In: Bowles ML \& CJ Whelan (eds) Restoration of endangered species: 90-117. Cambridge University Press, Cambridge, United Kingdom

WILLIAMS JL \& JK CONNER (2001) Sources of phenotypic variation in floral traits in wild radish, Raphanus raphanistrum (Brassicaceae). American Journal of Botany 88: 1577-1581.

ZIMMERMAN M (1980) Reproduction in Polemonium: competition for pollinators. Ecology 61: 497-501. 
